\title{
Probiotics Inhibit Lipopolysaccharide-Induced Interleukin-8 Secretion from Intestinal Epithelial Cells
}

\author{
Hyun Wook Oh, Gi Hoon Jeun, Jin Lee, Tae Hoon Chun ${ }^{1}$, and Sae Hun Kim \\ Division of Food Bioscience and Technology, Korea University, Seoul 136-701, Korea \\ ${ }^{1}$ Division of Biotechnology, Korea University, Seoul 136-701, Korea
}

\begin{abstract}
It has been suggested that probiotics could be useful for the prevention of symptomatic relapse in patients with inflammatory bowel disease (IBD). Interleukin (IL)-8 has been well recognized as one of the pro-inflammatory cytokines that could trigger inflammation and epithelial barrier dysfunction. In this study, the anti-inflammatory effects of probiotics were investigated using a human epithelial cell line (HT-29). Probiotics from infant feces and kimchi were tested for their cytotoxicity and effects on adhesion to epithelial cells. The present results show that seven strains could form $70 \%$ adhesion on HT- 29 . The probiotics used in this study did not affect HT-29 cell viability. To screen anti-inflammatory lactic acid bacteria, HT-29 cells were pretreated with live and heat-killed probiotics, and lipopolysaccharide (LPS) $(1 \mu \mathrm{g} / \mathrm{mL})$ was then added to stimulate the cells. The cell culture supernatant was then used to measure IL- 8 secretion by ELISA, and the cell pellet was used to determine IL-8 and toll-like receptor (TLR-4) mRNA expression levels by RT-PCR. Some probiotics (KJP421, KDK411, SRK414, E4191, KY21, and KY210) exhibited anti-inflammatory effects through the repression of IL-8 secretion from HT29 cells. In particular, Lactobacillus salivarius E4191, originating from Egyptian infant feces, not only decreased IL-8 mRNA expression, but also decreased TLR-4 expression. These results indicate that Lactobacillus salivarius E4191 may have a protective effect in intestinal epithelial cells.
\end{abstract}

Key words: anti-inflammatory, probiotics, interleukin-8, inflammatory bowel disease

\section{Introduction}

Probiotics are defined as living food supplements or components of bacteria that have beneficial effects on human health (Salminen et al., 1998). Most probiotics are derived from bacteria that naturally colonize the human intestine. To be considered beneficial, a probiotic bacterium must fulfill certain criteria, which include a human origin, generally regarded as safe (GRAS) status, acid and bile stability, adherence to intestinal cells, persistence for some time in the gut, the ability to produce antimicrobial substances, antagonism against pathogenic bacteria, and the ability to modulate the immune response (Dunne et al., 2001). Probiotic activity has been associated with lactobacilli, bifidobacteria, streptococci, enterococci, nonpathogenic Escherichia coli, and Saccharomyces boulardii (Shanahan, 2001).

Inflammatory bowel diseases (IBDs), including Crohn's

*Corresponding author: Sae-Hun Kim, Division of Food Bioscience and Technology, Korea University, Seoul 136-701, Korea. Tel: 822-3290-3055, E-mail: saehkim@korea.ac.kr disease and idiopathic ulcerative colitis, altered gut permeability, mucosal inflammation, and ulceration are present (Mankertz and Schulzke, 2007). The intestinal microbiota in patients with IBD seems to drive an overactive immune response, which leads to disease expression and concurrent morbidity (Shanahan and Bernstein, 2009). The potential for probiotics to modulate the intestinal microbiota, to provide beneficial immunomodulatory effectors, and to restore epithelial barrier defects suggests that a probiotic strategy might prove a viable future treatment option for patients with IBD.

The normal intestinal microflora, which is estimated to consist of 400 different bacterial species, reaches the highest concentrations in the terminal ileum and colon (Chung et al., 1975). Intestinal microflora produces toxic compounds such as Gram-negative bacterial endotoxin and harmful enzymes (e.g., $\beta$-glucuronidase and tryptophanase), which produce cytotoxic or carcinogenic agents (Rhodes et al., 1985). Cytotoxins and endotoxins may interact on the apical intestinal surface and induce a response in intestinal epithelial cells, which produce proinflammatory cytokines and other mediators of inflamma- 
tory activation of the mucosal immune system via tolllike receptor (TLR) and/or cytokine receptor signaling (Jung et al., 1995). Intestinal epithelia are capable of releasing some pro-inflammatory cytokines such as interleukin-8 (IL-8), and can response to enteric pathogens and release some pro-inflammatory cytokines, which in turn direct the movement of inflammatory cells of the lamina propria (Gewirtz et al., 1998). Intestinal epithelial cells were thought to be the first and most important probiotic action targets. Alterations in epithelial barrier function have been implicated in a variety of intestine-related disorders, including enteric infections, IBD, food allergy, autism, and stress (Turner, 2006). Current reviews have summarized the factors initiating and perpetuating IBD from 4 basic viewpoints: genetics, immune dysregulation, barrier dysfunction, and the role of microbial flora (Kucharzik et al., 2006).

Preclinical in vivo and in vitro studies have been undertaken to delineate the mechanisms underlying the beneficial effects of probiotics in IBD. Several in vitro studies have identified the signaling pathways involved in the interaction between lactobacilli and epithelial cells. Probiotics have been suggested to strengthen the epithelial barrier through various mechanisms, such as induction of mucin secretion, up-regulation of cytoprotective heat shock proteins (Petrof et al., 2004), enhancement of tightjunction function, and prevention of epithelial cell apoptosis (Mennigen et al., 2009).

The aim of study was to screen anti-inflammatory probiotic strains by measuring IL-8 production in lipopolysaccharide (LPS)-stimulated human intestinal epithelial HT-29 cells, to develop a combination of these strains that has synergetic effects on the inflamed model cells, and confirm the findings by mechanism analysis.

\section{Materials and Methods}

\section{Bacterial strains and culture medium}

The probiotic strains used in this study were obtained from the Food Microbiology Laboratory at Korea University (Seoul, Korea). The strains were originally isolated from Korean infant feces, Egyptian infant feces, and kimchi, that are listed in Table 1. The strains were cultured in de Man, Rogosa, Sharpe (MRS) broth (Difco, USA) at $37^{\circ} \mathrm{C}$ for $18 \mathrm{~h}$. The stock cultures were maintained at $-80^{\circ} \mathrm{C}$ with $50 \%$ glycerol as a cryoprotectant. The strains were subcultured 3 times prior to use.
Table 1. Probiotic strains used in this study

\begin{tabular}{cl}
\hline \hline Origin & \multicolumn{1}{c}{ Strain } \\
\hline Korean & Lactobacillus plantarum KM13 \\
infant & Lactobacillus plantarum KM29 \\
feces & Lactobacillus brevis KY21 \\
(4 strains) & Lactobacillus plantarum $\mathrm{KY} 210$ \\
\hline Egyptian & Lactobacillus. salivarius $\mathrm{E} 11$ \\
infant & Lactobacillus fermentum $\mathrm{E} 30 \mathrm{~L}$ \\
feces & Lactobacillus fermentum $\mathrm{E} 432 \mathrm{~L}$ \\
(5 strains) & Lactobacillus fermentum $\mathrm{E} 464 \mathrm{~L}$ \\
& Lactobacillus salivarius $\mathrm{E} 4191$ \\
\hline & Lactobacillus salivarius SWW308 \\
& Leuconostoc mesenteroides subsp. mesenteroides SKR310 \\
& Lactobacillus fermentum QWW311 \\
Kimchi & Leuconostoc mesenteroides subsp. mesenteroides KFM402 \\
(10 & Leuconostoc mesenteroides subsp. mesenteroides MSK408 \\
strains) & Leuconostoc mesenteroides subsp. mesenteroides KDK410 \\
& Leuconostoc mesenteroides subsp. mesenteroides KDK411 \\
& Leuconostoc mesenteroides subsp. mesenteroides SRK414 \\
& Lactobacillus curvatus KFP419 \\
& Leuconostoc paramesenteroides KJP421
\end{tabular}

\section{Heat killed (HK) bacteria}

The strains were sub-cultured 3 times in MRS broth at $37^{\circ} \mathrm{C}$ for $18 \mathrm{~h}$. Cultured cells were harvested by centrifugation at 11,336 $\mathrm{g}$ for $5 \mathrm{~min}$, and then washed 3 times with Phosphate Buffered Saline (PBS). These cell pellets were suspended in PBS and heat-treated at $95^{\circ} \mathrm{C}$ for $1 \mathrm{~h}$. The bacteria were then centrifuged, resuspended in PBS, and stored. The suspended cells were frozen at $-80^{\circ} \mathrm{C}$ overnight, and then the cells were dried under vacuum for $48 \mathrm{~h}$ in a freeze dryer (Ilshin LabCo, Korea). Freeze-dried cells were suspended at RPMI 1640 medium (HyClone) containing $10 \%$ fetal bovine serum (FBS) without penicillin-streptomycin, and used immediately.

\section{Adhesion assay}

HT-29 cells were seeded in 24-well plates at a concentration of $5 \times 10^{5}$ cells/well and cultured in $1 \mathrm{~mL}$ of RPMI 1640 medium (without penicillin-streptomycin) until 95\% confluent. Subcultured (3 times) probiotic strains were harvested by centrifugation at $11,336 \mathrm{~g}$ for $5 \mathrm{~min}$, and then washed 3 times with PBS. The cell pellets were resuspended in RPMI 1640 medium (without penicillinstreptomycin), and then probiotics were added at $1 \times 10^{9}$ $\mathrm{CFU} / \mathrm{mL}$ to $\mathrm{HT}-29$ cells and incubated for $2 \mathrm{~h}$ at $37^{\circ} \mathrm{C}$ in $5 \% \mathrm{CO}_{2}$. After incubation, the HT-29 cell monolayers were washed 6 times with PBS to remove non-attached bacteria. The adherent cells were released from the wells with $0.1 \mathrm{~mL}$ of trypsin-EDTA (HyClone, USA) and plated onto MRS agar. 


\section{Proliferation assay}

Cell proliferation was assessed by the 3'-(4,5,-dimethylthiazole-2-yl)-2,5-diphenyl-tetrazolium bromide (MTT) assay. HT-29 cells $\left(1 \times 10^{4}\right.$ cells/well $)$ were seeded in duplicate in 96 well plates and cultured in $200 \mu \mathrm{L}$ of RPMI 1640 medium for $24 \mathrm{~h}$. After treatment with live and heat-killed probiotics for $24 \mathrm{~h}, 100 \mu \mathrm{L}$ of medium was removed from the plate, $2 \mathrm{mg} / \mathrm{mL}$ MTT solution (Thiazolyl Blue Tetrazolium Bromide, Sigma, USA) was added, and the plate was incubated at $37^{\circ} \mathrm{C}$ for $2 \mathrm{~h}$. The optical density (OD) was measured at $540 \mathrm{~nm}$ using an ELISA reader (Molecular Devices, USA). Cell viability was calculated relative to untreated control cells as follows: (viability $(\%$ control $)=100 \times($ absorbance of treated sample $) /$ (absorbance of control)).

\section{Cells culture and stimulation}

A human epithelial cell (HT-29) line was obtained from the Korea Cell Line Bank (KCLB, Korea). The cells were routinely cultured at $37^{\circ} \mathrm{C}$ and $5 \% \mathrm{CO}_{2}$ in RPMI 1640 medium (HyClone) supplemented with 10\% heat-inactivated fetal bovine serum (FBS) (HyClone) and 1\% penicillin/streptomycin (HyClone). For the experiments, HT29 cells were seeded in a 6-well plate (Palcon, USA) at 1 $\times 10^{6}$ cells/well. After $24 \mathrm{~h}$, the medium was replaced with fresh RPMI 1640 medium without penicillin/streptomycin, and the cells were pre-treated with the probiotic strains for $2 \mathrm{~h}$ at $37^{\circ} \mathrm{C}$ in $5 \% \mathrm{CO}_{2}$, and then LPS (Escherichia coli O111:B4, Sigma, USA) was added at $1 \mu \mathrm{g} / \mathrm{mL}$ and incubated for $24 \mathrm{~h}$ to stimulate the cells. The negative control group was not stimulated with LPS.

\section{Reverse transcription polymerase chain reaction (RT-PCR)}

Total cellular RNA was isolated from the HT-29 cells using TRIZOL ${ }^{\mathrm{TM}}$ (Invitrogen, USA), and was further purified using acidic phenol-chloroform extraction. RNA integrity was assessed by electrophoresis on a denaturing $1.5 \%$ agarose gel.

Then, $3 \mu \mathrm{g}$ of total RNA was reverse transcribed in a
$20 \mu \mathrm{L}$ reaction mixture with the SuperScript ${ }^{\mathrm{TM}}$ III FirstStrand Synthesis System for RT-PCR (Invitrogen, USA). Next, cDNA was amplified using Taq DNA polymerase (GENENMED Inc., Korea). PCR was performed with a GeneAmp PCR System 2400 (Applied Biosystems, USA). For IL-8, pre-denaturation for $3 \mathrm{~min}$ at $95^{\circ} \mathrm{C}$ was followed by 30 cycles of $30 \mathrm{~s}$ at $95^{\circ} \mathrm{C}$ (denaturation), $30 \mathrm{~s}$ at $65^{\circ} \mathrm{C}$ (annealing), and $30 \mathrm{~s}$ at $72^{\circ} \mathrm{C}$ (elongation). The last cycle was followed by a $10 \mathrm{~min}$ final elongation at $72^{\circ} \mathrm{C}$. For TLR-4, the reaction included 28 cycles of $45 \mathrm{~s}$ at $95^{\circ} \mathrm{C}$ (denaturation), $45 \mathrm{~s}$ at $54^{\circ} \mathrm{C}$ (annealing), and $1 \mathrm{~min}$ at $72^{\circ} \mathrm{C}$ (extension). Primer sequences (Bioneer, Korea) used for the amplification of gene fragments are described in Table 2.

The RT-PCR products were electrophoresed in a $2 \%$ agarose gel and visualized by ethidium bromide (EtBr) staining. All results were normalized to GAPDH expression.

\section{Enzyme linked immunosorbent assay (ELISA)}

IL-8 was quantified in the cell culture supernatants using the human IL-8/NAP-1 immunoassay kit (Invitrogen, USA) according to the manufacturer's instructions with an ELISA reader (Molecular Devices, USA). In these assays, the lower and upper limits of detection were 5 and $1,000 \mathrm{pg} / \mathrm{mL}$, respectively.

\section{Statistical analysis}

The results are expressed as the mean \pm SEM. Data were analyzed statistically with SPSS software (version 12.0KO) (SPSS Inc., USA). Differences between groups were assessed for statistical significance using the Student's $t$ test. Asterisks (*) indicate a significant difference at less than 0.05 . Unless stated otherwise, all data presented were mean values of duplicates, obtained from two separate runs.

\section{Results and Discussion}

\section{Adhesion abilities of probiotics}

The etiology of ulcerative colitis is still unclear. How-

Table 2. Primer sequences for reverse transcription PCR

\begin{tabular}{|c|c|c|c|c|}
\hline Gene name & Primer direction & Sequence (5'-3') & Size (bp) & Reference \\
\hline \multirow{2}{*}{ IL-8 } & Forward & GTTGTGAGGACATGTGGAAGCACT & \multirow{2}{*}{359} & GenBank \\
\hline & Reverse & CACAGCTGGCAATGACAAGACTGG & & NM_000584 \\
\hline \multirow{2}{*}{ GAPDH } & Forward & ATGACCACAGTCCATGCCATC & \multirow{2}{*}{271} & GenBank \\
\hline & Reverse & СCTGCTTCACCACCTTCTTG & & NM_0020463 \\
\hline \multirow{2}{*}{ TLR-4 } & Forward & GACGTGGAACTGGCAGAAGAGG & \multirow{2}{*}{502} & \multirow{2}{*}{ Chang et al. (2006) } \\
\hline & Reverse & TGACGGCAGAGAGGAGGTTGAC & & \\
\hline
\end{tabular}


ever, increased aberrant enteric microflora, including harmful and potentially harmful bacteria, and decreased normal microflora, such as bifidobacteria and lactobacilli, have been regarded as an important pathogenic factor. It is believed that abnormal interactions between the colonic mucosal immune system and aberrant enteric microflora result in altered intestinal immunological function and trigger the inflammatory disease process (Fedorak and Madsen, 2004).

To evaluate whether the anti-inflammatory effect of probiotics is a result of a secreted factor, or if it requires contact between probiotics and cells, adhesion ability was assessed after $2 \mathrm{~h}$ of co-culture. Lactobacillus rhamnosus GG was used as positive control. Seven of the probiotic strains (Leuconostoc paramesenteroides KJP421, Lactobacillus salivarius E4191, Leuconostoc mesenteroides subsp. mesenteroides KFM402, Leuconostoc mesenteroides subsp. mesenteroides KDK411, Leuconostoc mesenteroides subsp. mesenteroides SRK414, Lactobacillus brevis KY21, and Lactobacillus plantarum KY210) were selected for their strong interaction with HT-29 cells, with adhesion values of greater than $70 \%$ of the inoculated bacteria. In contrast, Lactobacillus salivarius SWW308 showed the lowest adhesion capacity at $45.7 \%$ (Fig. 1).

\section{Effect of live and heat-killed probiotics on cell pro- liferation}

Most studies of the immunomodulatory effects of lactic acid bacteria have focused on viable microorganisms. However, heat-killed lactic acid bacteria not only possess immunomodulatory functions (Chuang et al., 2007; Pochard et al., 2002; Sashihara et al., 2006), but also pro-

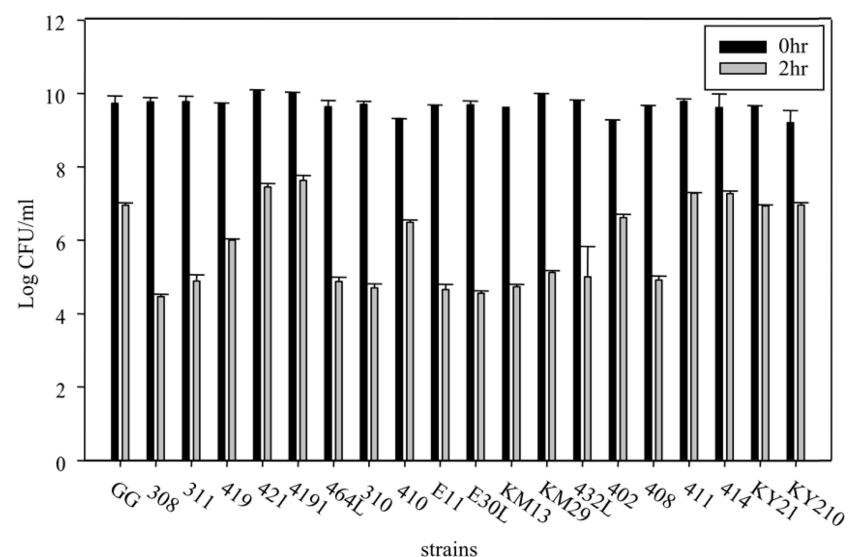

Fig. 1. Adherence of probiotic strains to intestinal epithelial HT-29 cells. $1 \times 10^{9} \mathrm{CFU} / \mathrm{mL}$ of each strain were cultured with a mono layer of HT-29 cells for 2 h. After washing 6 times with PBS, adherent bacteria were plated on de Man, Rogosa, Sharpe (MRS) agar. vide the advantages of a longer product shelf life, easier storage, and more convenient transportation.

This study attempted to establish appropriate conditions for heat killed probiotics with immunomodulatory functions. Before measuring IL-8 secretion from HT-29, any possible toxicity of both the live and heat-killed probiotics was investigated. The MTT assay results indicated that cell viability was not affected by the lactic acid bacteria used in this study (Fig. 2).

\section{Lipopolysaccharide (LPS)-induced IL-8 up-regula- tion}

Neutrophil infiltration into inflammatory sites is a hallmark of acute inflammation. Locally produced chemotactic factors are thought to mediate the sequence of events leading to infiltration at inflammatory sites. IL-8, a novel leukocyte chemotactic activating cytokine (chemokine), is produced by various cell types in response to inflammatory stimuli, and exerts various effects on leukocytes, particularly neutrophils in vitro (Harada et al., 1994).

IL-8 production has been observed in vitro in a wide variety of cells, including monocytes, $\mathrm{T}$ lymphocytes, neutrophils, vascular endothelial cells, dermal fibroblasts, keratinocytes, hepatocytes, and human gastric cancer cells (Yasumoto et al., 1992). Moreover, although IL-8
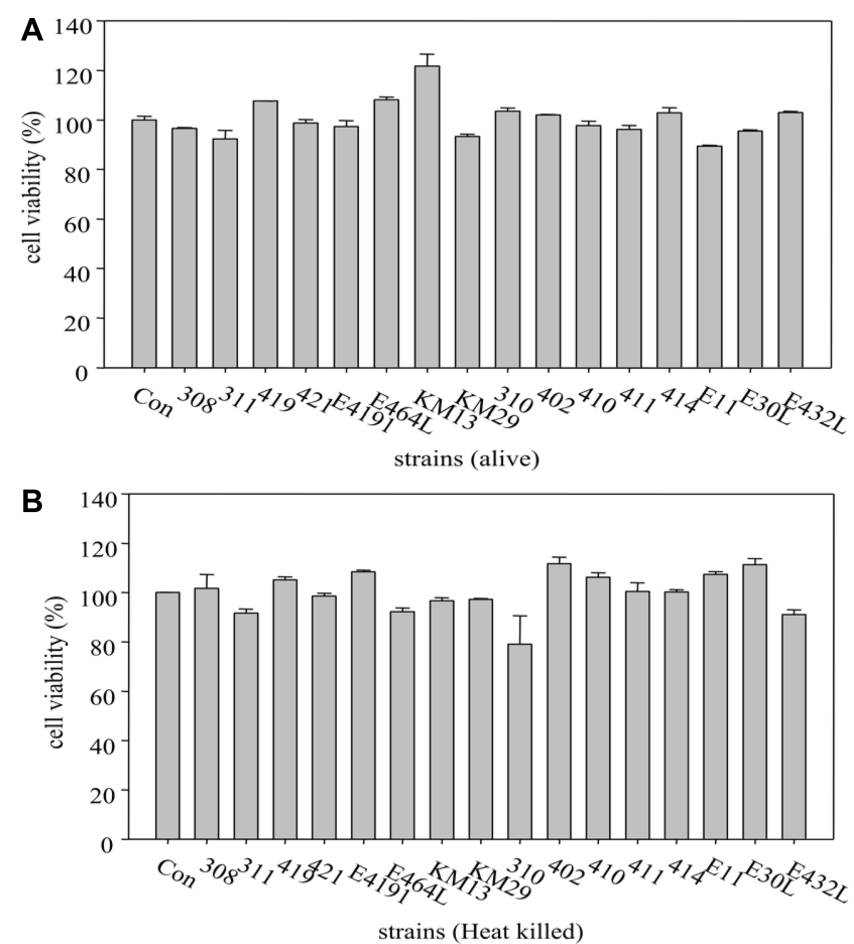

Fig. 2. Effects of live and heat-killed probiotics on cell viability. (A) Live probiotic, (B) Heat-killed probiotic. $1 \times 10^{6}$ bacteria were co-cultured with $1 \times 10^{4}$ cells at $37^{\circ} \mathrm{C}$ for 24 $\mathrm{h}$, and then the MTT assay was performed. 


\section{IL-8}

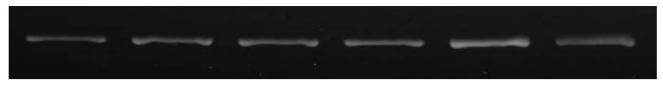

GAPDH
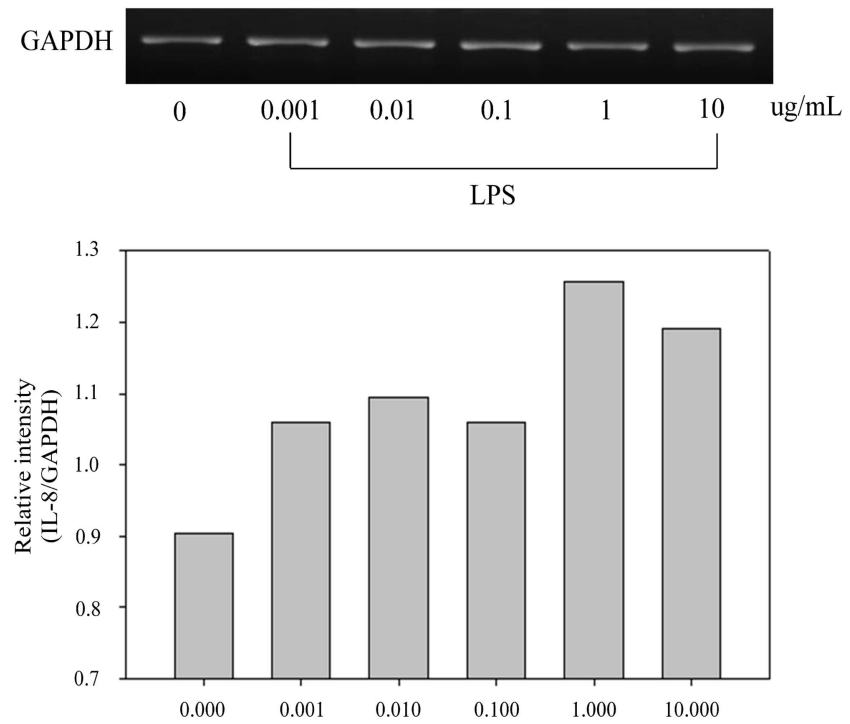

Fig. 3. Lipopolysaccharide induced interleukin (IL)-8 secretion from HT-29 cells. HT-29 cells were stimulated with $1 \mathrm{ng} / \mathrm{mL}, 10 \mathrm{ng} / \mathrm{mL}, 100 \mathrm{ng} / \mathrm{mL}, 1 \mu \mathrm{g} / \mathrm{mL}$, and $10 \mu \mathrm{g} / \mathrm{mL}$ LPS for 24 h. Expression of IL-8 was measured by RTPCR.

production is not constitutive, it usually occurs in the presence of inflammatory stimuli such as LPS, IL-1, and tumor necrosis factor (TNF). In fact, IL-8 is not detected in normal adult plasma, but intravenous injection of LPS induces a massive elevation of plasma IL-8 (Martich et al., 1991).

Our experiments measured IL-8 production in LPSstimulated human intestinal epithelial HT-29 cells. To determine the optimal dose of LPS for IL- 8 production, LPS ( $1 \mathrm{ng} / \mathrm{mL}, 10 \mathrm{ng} / \mathrm{mL}, 100 \mathrm{ng} / \mathrm{mL}, 1 \mu \mathrm{g} / \mathrm{mL}$, and $10 \mu \mathrm{g} /$ $\mathrm{mL}$ ) was incubated with HT-29 cells for $24 \mathrm{~h}$. At a concentration of $1 \mu \mathrm{g} / \mathrm{mL}$, LPS significantly induced IL-8 production (Fig. 3). This concentration was then used in all subsequent experiments.

\section{Live and heat-killed probiotics inhibited LPS- induced up-regulation of IL-8}

To assess the anti-inflammatory properties of the probiotic strains, IL-8 production was evaluated by incubating HT-29 cell monolayers with LPS in the presence of the probiotic strains listed in Table 1.

Inhibition of IL-8 production was most effective when the ratio of cells to lactic acid bacteria was $1: 10$. To screen the anti-inflammatory lactic acid bacteria, $1 \times 10^{7} \mathrm{CFU}$ of bacteria were added to $1 \times 10^{6}$ HT-29 cells. After a 2-h incubation, the cells were stimulated with $1 \mu \mathrm{g} / \mathrm{mL}$ LPS
A
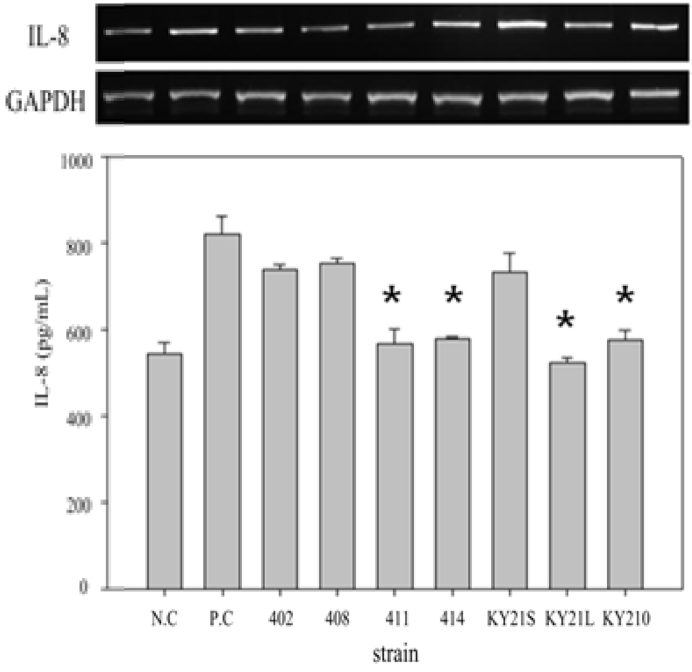

B
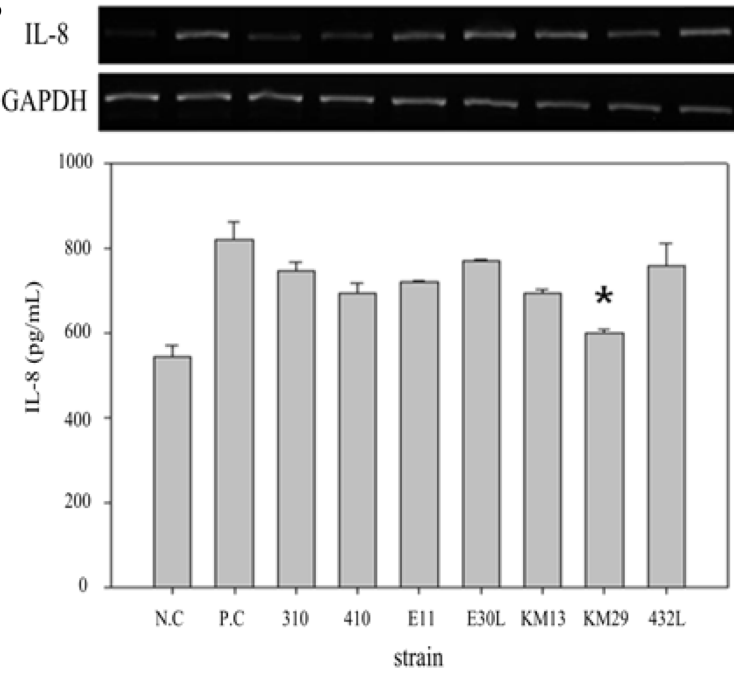

C

IL-8
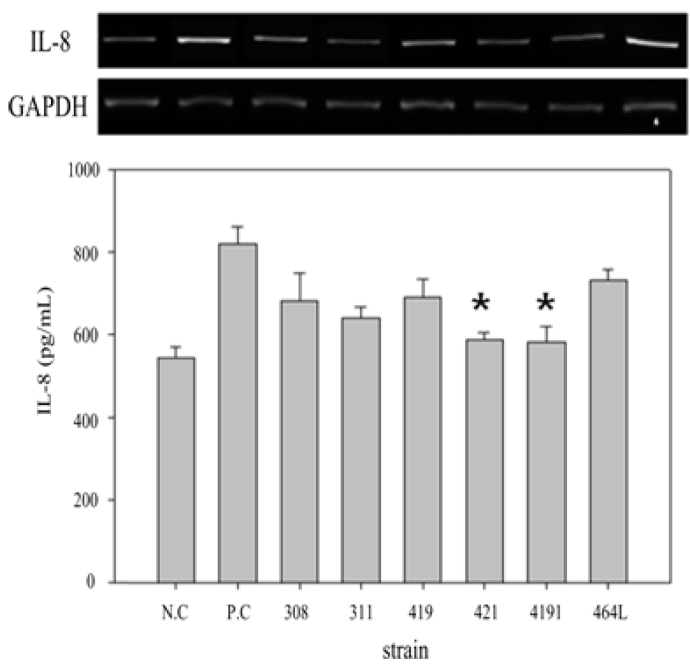

Fig. 4. Live probiotic strains induce IL-8 secretion from human intestinal epithelial cells (A, B, C). HT-29 cells $\left(1 \times 10^{6}\right)$ were pre-treated with $1 \times 10^{7}$ bacteria at $37^{\circ} \mathrm{C}$ for 2 $\mathrm{h}$, and then $1 \mu \mathrm{g} / \mathrm{mL}$ of LPS was added and incubated for $24 \mathrm{~h}$. The supernatant was used for ELISA, and the cells were used for RT-PCR to measure IL-8 expression. * $p<$ 0.05 , LPS treatment group (P.C.) versus LPS untreated group (N.C.). 
for $24 \mathrm{~h}$.

As shown in Fig. 4, Leuconostoc paramesenteroides KJP 421, Lactobacillus salivarius E4191, Leuconostoc mesenteroides subsp. mesenteroides KDK 411, Leuconostoc mesenteroides subsp. mesenteroides SRK 414, Lactobacillus brevis KY21, and Lactobacillus plantarum KY210 reduced the secretion of IL- 8 by $71.6 \%$ (587.3 \pm $17.3 \mathrm{pg} / \mathrm{mL}), 71 \%$ (582.3 $\pm 37.9 \mathrm{pg} / \mathrm{mL}), 69.2 \%$ (567.2 \pm 32.6 $\mathrm{pg} / \mathrm{mL}), 70.6 \%(579 \pm 2.2 \mathrm{pg} / \mathrm{mL}), 63.7 \%(522.6 \pm 12.4 \mathrm{pg} /$ $\mathrm{mL})$, and $70.4 \%(577.6 \pm 20 \mathrm{pg} / \mathrm{mL})$, respectively. These lactic acid bacteria were used for further study. In contrast, most heat-killed lactic acid bacteria did not show any effects on IL-8 secretion except Lactobacillus salivarius E4191 (Fig. 5).

Toll-like receptors (TLRs), which serve as a major link between the innate and adaptive mucosal immune responses, act as transmembrane co-receptors with CD14 in the cellular response to LPS (Ingalls et al., 1999). TLR-4 is the primary mediator of LPS signaling (Cario and Pldolsky,

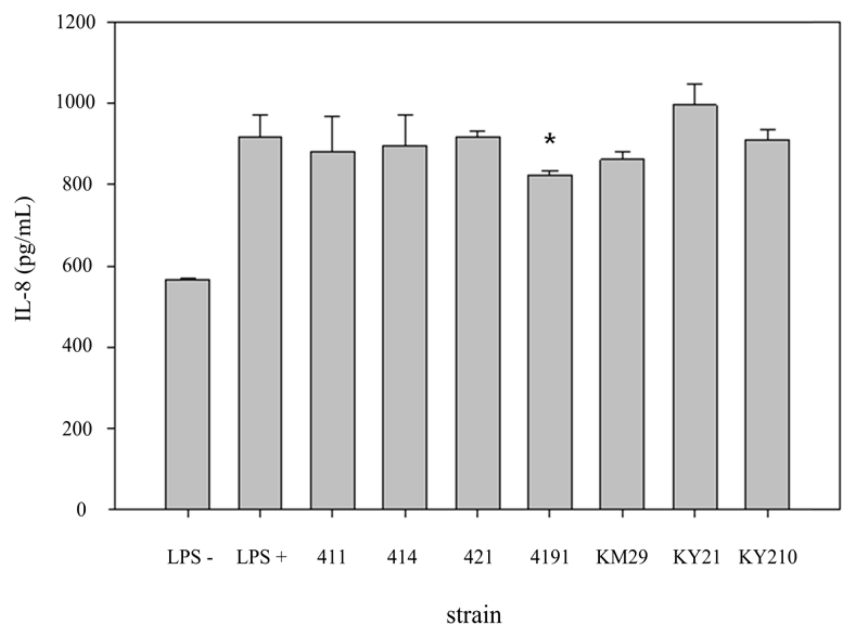

Fig. 5. Effect of heat-killed probiotic strains on IL-8 secretion from HT-29 cells. HT-29 cells $\left(1 \times 10^{6}\right)$ were pre-treated with $1 \times 10^{7}$ heat-killed bacteria at $37^{\circ} \mathrm{C}$ for $2 \mathrm{~h}$, and then 1 $\mu \mathrm{g} / \mathrm{mL}$ of LPS was added and incubated for $24 \mathrm{~h}$. The supernatant was used for ELISA, and the cells were used to measure IL-8 expression by RT-PCR.

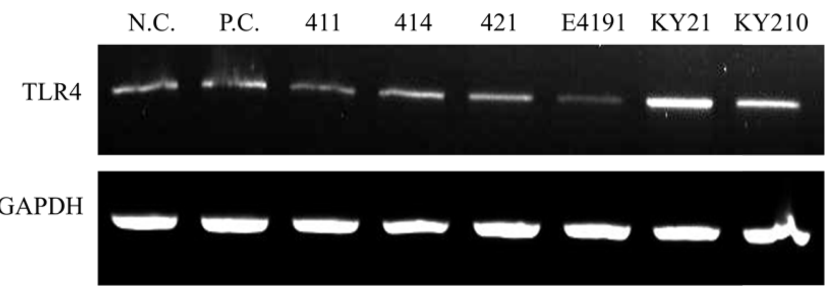

Fig. 6. Effects of probiotics on TLR4 expression in LPS-stimulated HT-29 cells. HT-29 cells were pre-treated for with each probiotic for $2 \mathrm{~h}$ before stimulation with LPS for 24 h. LPS treatment group (P.C.); LPS untreated group (N.C.).
2000). As shown in Fig. 6, live Lactobacillus salivarius E4191 also decreased TLR-4 expression. These data show that lactic acid bacteria directly affect intestinal epithelial cells, and the adhesion ability previous shown supports this conclusion.

\section{Acknowledgments}

This study was supported by a Korea University grant, and by Korea Institute of Planning and Evaluation for Technology in Food, Agriculture, Forestry, and Fisheries (IPET) (No. 108141-03), the Ministry for Food, Agriculture, Forestry, and Fisheries, Republic of Korea.

\section{References}

1. Cario, E. and Pldosky, D. K. (2000) Differential alteration in intestinal epithelial cell expression of toll-like receptor 3 (TLR-3) and TLR-4 in inflammatory bowel disease. Infect. Immun. 68, 1010-1017.

2. Chuang, L., Wu, K. G., Pai, C., Hsieh, P. S., Tsai, J. J., Yen, J. H., and Lin, M. Y. (2007) Heat-killed cells of lactobacilli skew the immune response toward $\mathrm{T}$ helper 1 polarization in mouse splenocytes and dendritic cell-treated $\mathrm{T}$ cells. $J$. Agric. Food Chem. 55, 11080-11086.

3. Chung, K. T., Fulk, G. E., and Slein, M. W. (1975) Tryptophanase of fecal flora as a possible factor in the etiology of colon cancer. J. Natl. Cancer Inst. 54, 1073-1078.

4. Dunne, C., O’Mahony, L., Murphy, L., Thornton, G., Morrisscy, D., O'Halloran, S., Feeney, M., Flynn, S., and Fitzgerald, G. (2001) In vitro selection criteria for probiotic bacteria of human origin: correlation with in vivo findings. Am. J. Clin. Nutr. 73, 386s-392s.

5. Fedorak, R. N. and Madsen, K. L. (2004) Probiotics and the management of inflammatory bowel disease. Inflamm. Bowel. Dis. 10, 286-299.

6. Gewirtz, A. T., McCormick, B., Neish, A. S., Petasis, N. A., Gronert, K., Serhan, C. N., and Madara, J. L. (1998) Pathogen-induced chemokine secretion from model intestinal epithelium is inhibited by lipoxin A4 analogs. J. Clin. Invest. 101, 1860-1869.

7. Harada, A., Sekido, N., Akahoshi, T., Wada, T., Mukaida, N., and Matsushima, K. (1994) Essential involvement of interleukin-8 (IL-8) in acute inflammation. J. Leukoc. Biol. 56, 559-564.

8. Ingalls, R. R., Heine, H., Lien, E., Yoshimura, A., and Glenbock, D. (1999) Lipopolysaccharide recognition, CD14, and lipopolysaccharide receptors. Infect. Dis. Clin. North Am. 13, 341-353.

9. Jung, H. C., Eckmann, I., Yang, S. K., Panja, A., Fierer, J., Morzycka-Worblewska, E., and Kagnoff, M. F. (1995) A distinct array of pro-inflammatory cytokines is expressed in human colon epithelia cells in response to bacterial invasion. J. Clin. Invest. 95, 55-65. 
10. Kucharzik, T., Maaser, C., Lugering, A., Kagnoff, M., Mayer, L., Targan, S., and Domschke, W. (2006) Recent understanding of IBD pathogenesis: Implications for future therapies. Inflamm. Bowel. Dis. 12, 1068-1083.

11. Mankertz, J. and Schulzke, J. D. (2007) Altered permeability in inflammatory bowel disease: Pathophysiology and clinical implications. Curr. Opin. Gastroenterol. 23, 379-383.

12. Martich, G. D., Danner, R. L., Ceska, M., and Suffredini, A. F. (1991) Detection of interleukin 8 and tumor necrosis factor in normal humans after intravenous endotoxin: The effect of anti-inflammatory agents. J. Exp. Med. 173, 1021-1024.

13. Mennigen, R., Nolte, K., Rijcken, E., Utech, M., Loeffler, B., Senninger, N., and Bruewer, M. (2009) Probiotic mixture VSL\#3 protects the epithelial barrier by maintaining tight junction protein expression and preventing apoptosis in a murine model of colitis. Am. Physiological. Soc. 296, 11401149.

14. Petrof, E. O., Kojima, K., Ropeleski, M. J., Musch, M. W., Tao, Y., De Simone, C.D., and Chang, E. B. (2004) Probiotics inhibit nuclear factor-kappaB and induce heat shock proteins in colonic epithelial cells through proteasome inhibition. Gastroenterol. 127, 1474-1487.

15. Pochard, P., Gosset, P., Grangette, C., Andre, C., Tonnel, A. B., Pestel, J., and Mercenier, A. (2002) Lactic acid bacteria inhibit TH2 cytokine production by mononuclear cells from allergic patients. J. Allergy Clin. Immunol. 110, 617-623.
16. Rhodes, J. M., Gallimore, R., and Elias, E. (1985) Fecal mucus degrading glycosidase in ulcerative colitis and Crohn's disease. Gut. 26, 761-765.

17. Salminen, S., Ouwehand, A. C., and Isolauri, E. (1998) Clinical applications of probiotic bacteria. Int. Dariy. J. 8, 563572.

18. Sashihara, T., Sueki, N., and Ikegami, S. (2006) An analysis of the effectiveness of heat-killed lactic acid bacteria in alleviating allergic diseases. J. Dairy Sci. 89, 2846-2855.

19. Shanahan, F. and Bernstein, C. N. (2009) The evolving epidemiology of inflammatory bowel disease. Curr. Opin. Gastroenterol. 25, 301-305.

20. Shanahan, F. (2001) Immunodiagnostics, immunotherapeutics, and ecotherapies. Gastroenterol. 120, 622-635.

21. Turner, J. R. (2006) Molecular basis of epithelial barrier regulation from basic mechanisms to clinical application. Am.J. Pathol. 169, 1901-1909.

22. Yasumoto, K., Okamoto, S., Mukaida, N., Murakami, S., Mai, M., and Matsushima, K. (1992) Tumor necrosis factor alpha and interferon gamma synergistically induce interleukin 8 production in a human gastric cancer cell line through acting concurrently on AP-1 and NF-kappaB-like binding sites of the interleukin 8 gene. J. Biol. Chem. 267, 2250622511.

$\overline{\text { (Received 2012.1.26/Revised 2012.5.29/Accepted 2012.7.24) }}$ 